\title{
Tertiary Teachers Strike (TTS) and e-Learning Deficit amidst Covid-19 Crisis in Nigeria
}

\author{
Victor Okoro Ukaogo ${ }^{1}$, Florence Onyebuchi Orabueze ${ }^{2} \&$ Chika Kate Ojukwu $^{3}$ \\ ${ }^{1} \mathrm{PhD}$, Professor, Department of History and International Studies, University of Nigeria, Nsukka. \\ Corresponding Author. Email: victor.ukaogo@unn.edu.ng \\ ${ }^{2} \mathrm{PhD}$, Professor, Department of English and Literary Studies, University of Nigeria Nsukka \\ Email: florence.Orabueze@unn.edu.ng \\ ${ }^{3} \mathrm{PhD}$, Lecturer, Department of English and Literary Studies, University of Nigeria Nsukka \\ Email: chika.ojukwu@unn.edu.ng
}

\begin{abstract}
Amid the raging Covid-19 pandemic across the world and the debilitating tertiary teachers strike in Nigeria, this study's objective seeks to examine the prevailing un-lived experiences of Nigerian tertiary students in e-learning. The study argues that Covid-19 has widened the digital divide between Nigerian universities and other universities in other parts of the world on the one hand and between public and private tertiary institutions in Nigeria on the other. This e-learning deficit is worsened by university teachers' strike, constituting a twin inhibition into which higher education is consigned in Nigeria. The study identifies poor funding of education as a major constraint to virtual learning and instruction faced by public tertiary students especially in the era of pandemic. Data collections for the study will be carried out through oral interviews basically focus group discussion (FGD) from a sample population of 50 university students (male and female) in three universities across the southeast region of Nigeria, newspaper reports, and participantobserver methods of research analysis.
\end{abstract}

\section{Keywords:}

e-learning; tertiary teachers, public universities, private universities, education; Covid-

19; ASUU strike, vaccine nationalism

\section{Introduction}

There is no gainsaying that the Coronavirus pandemic has adversely affected all aspects of our lives. The ravaging pandemic has created devastating and unprecedented situations that have gravely affected people's lives across the globe. Many countries including Nigeria have been affected by this pandemic and the World Health Organization (2020) has identified a novel strain of Coronavirus as the major cause. The global health organization declared the virus a pandemic on 11 March 2020 (Ajisegiri, Odusanya, \& Joshi, 2020:4) having killed over 100,000 people in over 
100 countries. With over 50,000 positive cases recorded as at yesterday (20th August 2020) in Nigeria coupled with rising doubts over how and when the pandemic will end (Lee et al., 2010:16), and $\mathrm{WHO}$ predicting two more years, the rise in vaccine nationalism pitching countries against each other, with current claims and counterclaims of breakthroughs in vaccine production, the situation is indeed dire and scary. Claims of cure are on the increase with several pre-clinical trials going on at the moment $(\mathrm{WHO}, 2020)$. There are opinions and believable conjectures that a vaccine might be available in November or December 2020 (McCarthy, 2020:20, Reynolds, and 2020:10). There is greater worry that even after the approval of a vaccine, that the vaccine will not be enough to go round the afflicted world population (Felter, 2020:42). The tertiary teachers strike in Nigeria has paralyzed the university system in the country. For many years, the university teachers' union has been at loggerhead with the government over sundry issues bordering on staff/student welfare and revitalization of the university system amongst many other demands. It will be recalled that in June 2009, university teachers were instructed to embark on an indefinite nationwide strike by the teachers' union - Academic Staff Union of Universities (ASUU) on account of disagreements it reached with the Federal Government about two and a half years earlier. The latest face-off in 2020 was sparked off

by the government's breach of the 2009 and 2012 agreement with the teachers and government unilateral decision to compel teachers to enroll in a 'dubious salary payment platform' called the Integrated Payment and Personnel Information System (IPPIS) that at the very best has emasculated the union by way of underpayment of salaries and the destruction of the autonomy of the universities (The Universities (Miscellaneous Provisions) (AMENDMENT) ACT 1993) as provided by an enabling Act of parliament.

On Monday March 9, 2020, the teachers' union asked its members to proceed on a warning strike of two weeks (Vanguard, March 10), which was followed by the declaration of an indefinite strike (Odoh, 2020:35) at the expiration of the two weeks warning strike. It was at this critical juncture that the pandemic sneaked into Nigeria. So, while teachers shut down the universities for the irreconcilable differences with the government, the National Universities Commission (NUC) affirmed the closure of universities on account of the pandemic. It is to be noted that school closures are only a temporary measure being 'a critical component or indeed a nonpharmaceutical prevention strategy adopted by many countries to ensure reduction in the number of cases if not slow the spread of the disease...' (Glass et al., 2006:9; Institute of Medicine, 2006; Moscona, 2005:15; Sadique et al., 2008:11). Put together, the tertiary educational system crumbled in the country and students from poor families are bearing the brunt of it as majority of them are enrolled in public universities.

By evidence, the twin burden of Covid-19 and the closure of tertiary institutions have yielded the imperative for the utilization of alternative means of teaching thus, the option of e-learning and other internet resource options. In many countries, educational institutions have hurried to shift courses to virtual classrooms (Maila, 2020) thus cancelling the conventional face-to-face contact in classes, laboratories and other academic activities to help avoid the spread of COVID-19. About 129 countries in the estimation of the UN Educational, Scientific, and Cultural Organization (UNESCO, 2020), had implemented closures at tertiary schools. In Nigeria, closures at the primary, post-primary and post-secondary levels were inevitable but alternative options of learning became a challenge. The primary objective in alternative learning option: "is not to re-create a 
stable educational environment, but rather to provide immediate access to education and training in a manner that is easy to develop and easily accessible during an emergency or crisis" (Maila, 2020:5). This probably explains why a scholar aptly christened the resort to e-learning option - the 'pandemic pedagogy' (Millman, 2020:3) and another referred to it as Emergency Remote Teaching (ERT) (Hodges et al, 2020:7) both of which represent a 'temporary change from instruction delivery to alternative delivery due to crisis circumstances. The big question is how prepared is Nigeria to switch to alternative mode of instruction delivery?

\section{The Causes of Tertiary Teachers' Strike}

Nigerian universities often embark on strikes to press home demands from government but it does appear many are unwilling to ask why. Many believe that ASUU is a radicalized union that employs confrontation as a tool of engagement with government (Vanguard, 2020). Not a few also believe that government has been insincere with teachers with no commitment to provide funding to the universities to improve quality and standard (Ogbette, 2018:15). Otobo (1988:308) believes that university strikes have not received commensurate attention. ASUU is not alone in using strikes as weapon of negotiation with government as several groups have adopted same strategy. It is worth noting that before 2003, striking teachers had always anchored their industrial strikes on the fear of a possible loss of autonomy and academic freedom provided by a Parliamentary Act, poor remuneration, abysmal treatment poor funding and avoidable delays in the payment of salaries. (Ogbette et al, 2017:14, Adavbiele, 2015, Osabuohien and Ogunrinola, 2015). ASUU President, Professor Biodun Ogunyemi have repeatedly told the public of government's breaching of the 2013 agreement in improving tertiary institutions and presently owe over a trillion Naira to these universities and worse still poor budgetary provision of not more than $6 \%$ remain a major challenge in education financing. In summary, the current strike revolves around the same old demands of revitalizing the universities; abrogate the forceful imposition and enrollment of university teachers into the IPPIS payment platform without teachers' consent on universities as well as stopping the proliferation of universities if the government lacks the willingness or capacity to fund the said universities amongst others.

While many are sad that government remain ill-concerned about its regular breaching of agreements with teachers as evidenced in the non-implementation of 'agreements agreed upon by both parties via memoranda in 2013, 2017 and 2019', others are at a loss why issues of corruption and sharp practices persist in the ivory towers in Nigeria. The teachers that are yet to ask for increment in their salaries and allowances may be protecting their interests; the truth could be that the teachers' union is more interested in upgrading the competitive quality of Nigerian universities.

\section{COVID-19 Arrives Nigeria}

An Italian who works in Nigeria flew into Lagos from Milan on the 25 February 2020 and had contact with a Nigerian from Ogun State and on the 27 February 2020, he was diagnosed with Covid-19. This was announced as the index case being the first recorded case of Covid-19 in the country (NCDC, 2020). The news came not as a surprise because 
earlier before that date, a legislative member at the National Assembly in Abuja raised alarm over the absence of security personnel at the various International Airports in Nigeria whose responsibility ordinarily should be to conduct a routine check of every passenger on arrival. Coronavirus disease 2019 (COVID-19), had its origins in Wuhan China where it was first reported late 2019. The disease grew into a serious global health challenge when it killed over 100,000 people in 100 countries ((Callaway, 2020) and was thereafter declared a pandemic. With weak and fragile health infrastructure, Africa is a critical playground for the pandemic and given Nigeria's poor infrastructure, response to the pandemic was a major source of concern. Outside the health challenge, the pandemic has grim implications for Nigeria, especially as the lockdown affected the movement of goods, services and humans. The lessons emanating from the Covid19 outbreak requires a sustained interrogation of our understanding of the pandemic on the one hand and a detailed appraisal of the various e-learning options for students and teachers not to stagnate the sector.

\section{Research Questions}

The following research questions frame this study:

1. What impact has ASUU strike had on tertiary education in Nigeria?

2. How did COVID-19 enter Nigeria?

3. What impact has COVID-19 had on Nigeria's education sector and how can this be ameliorated?

\section{Literature Review: Very Close; yet so far}

Ajisegiri et al (2020) reviewed the historical origin of the pandemic but particularly examined it within the context of its outbreak in Nigeria and the need for effective response using community health workers. (Kari Mugo, Naliaka Odera and Maina Wachira (2020) examined the impact of COVID-19 scourge on Africa's higher education and research sector. With all research efforts directed towards the advanced western countries, the focus of this study essentially tilt towards Africa with the submission that academic and research institutions found themselves tasked with learning how to adapt during the COVID-19 pandemic that has significantly ruptured higher education in the continent. Pandemic and Infectious disease outbreaks of large proportion, such as COVID-19, require enormous attention beyond the routine attitudes of aloofness because in terms of resources and procedures, 'they tend to significantly impact on the economy and health systems' of nations (Boyce, 2020). There is no doubt that these impacts are usually more pronounced at the community level where a preponderant number of the populations are domiciled.

Buonsenso et al (2020) examined the social consequences of COVID-19 in a low resource setting like Sierra Leone. It set out to address the social impact of the pandemic on a rural village with possible economic and psychological consequences. The study averred that the effect of the 
pandemic on this rural community is similar to other African communities. Dube (2020) discusses constraints faced by poor learners in South Africa where they experience unprecedented problems attempting to adjust to a new instructional mode of learning especially for students in the area of learning management systems and low-tech applications. The study held that 'in the fight against COVID-19, it is critical that human rights, especially those of rural learners, are respected and that the Department of

Basic Education should take an all-inclusive approach to address the lived realities of rural learners. When all people are included in all processes, including learning, it will facilitate the easy flow of information, which is essential in the fight against COVID-19'.

There should be a resort to an alternative route to learning Krishnakumar and Rana (2020) different from the traditional methods of teaching and learning. This represents a different task to rural learners, where a teacher appears physically to students; monitoring them at close quarters. Essentially, researchers and scientists confirm that the most enduring route to check the spread against the spread of COVID-19 is ensuring the compliance on the severally outlined preventive protocols outlined by the NCDC. In this era of the pandemic, therefore, traditional teaching and learning are no longer permissible. The fallout from this is the daunting fear that learning with e-learning options will alienate a significant population of the underprivileged students by serving a minority from affluent homes with access to internet resources

To buttress the inequality and inequity in learning at times such as this, Ebrahim, Ahmed, Gozzer, Schlagenhauf and Memish (2020) informed that the state of lockdown in Nigeria and several other places as a check on the spread of COVID-19 created a colony of helpless teachers and learners; being helpless on how to approach online learning during the COVID-19 lockdown, and halted the economic services and products within and without a country. This widened the gap and chasm between the rich with the ability to provide internet resources and the poor without such capacity. From the foregoing, online learning has become inevitable being a practicable alternative to traditional schooling but this opens up a new challenge of alienation and absence of inclusion in the lived realities of poor and rural learners. Sadly, what is considered a response to counter the pandemic has become a problem of a sort as it 'isolates some sections of the population because they lived in deprived communities' with poor access to regular electricity, affordable data and expertise. This probably explains Nkoane's (2010:113-114) position of opposition aligned towards undermining rights of rural learners. On the reality of the above, we align ourselves to the position held by Du Plessis and Mestry (2019), that there is a 'need to put strategies in place to improve the working conditions of teachers and the teaching' to improve a lot for the learner and the teacher. On alienating the rural dwellers and the imperative for allinclusive policy in the learning processes during the pandemic, Shibeshi (2006) opined that solutions should respond to the needs of the poor. Since the majority of Nigeria's youth and schooling are domiciled in the rural areas, our submission is unique as it encapsulates the lived realities of rural teachers and students thus the imperative to protect their rights in the articulation and implementation of policies in this era of the pandemic.

ASUU is insistent that the Integrated Personnel and Payroll Information (IPPIS) salary scheme will erode university autonomy. Furthermore, ASUU position that its 2009 agreement with the Federal government is yet to be met by the federal government on the welfare of her members and in the 
area of infrastructural developments in the universities was also another issue of neglect. Meanwhile, ASUU disagreement with FG was heightened by the ability of the union to provide an alternative salary scheme known as University Transparency and Accountability Solution (UTAS) when they had discussions with the government. After four months without salary, the Federal Government considered it as part of the Covid-19 policy of palliatives to pay salaries of university teachers. Just as the plans to pay teachers were put in motion, there was a demand from the federal government to university teachers to provide Bank Verification Number (BVN) as a prerequisite to pay their salaries. In response, the union insists that the Federal Government does not require BVN to pay salaries but in a move to checkmate what has been described as deliberate intention to enrol academics into IPPIS to checkmate primitive acquisition was the rationale for demanding the BVN (Uchegbu, 2020:17). The federal government upon ASUU refusal to submit BVN illegally obtained BVNs of all university staff from the Central Bank of Nigeria (CBN)(Dike,2020:28) and paid salaries that were not commensurate with workers current earnings. There were cases of retired and dead staff who were paid (Dike,2020:26) showing, in reality, the efficacy and efficiency of the new payment platform into which university teachers were forcefully enrolled.

\section{Theoretical Framework: Critical Emancipatory Research (CER)}

This study is guided by the guidelines provided by Critical Emancipatory Research (CER) evidenced in the ideas of Emmanuel Kant. Theoretical lens of Critical Emancipatory Research (CER) is utilized to interrogate the challenge of learning in the era of COVID-19. CER sprouted from the intellectual traditions of the Marxist School of critical Inquiry of the University of Frankfurt in 1823 where Marxist perspective on economic and social questions held sway (Schmidt,_2007:51). Some scholars, such as McKernan (2013), 'trace the ideas of CER to Emmanuel Kant, a German philosopher, who first hinted at critical theory in 1871'. CER was founded by the son of a wealthy German business mogul named Mr Weil who created an innovative brand of philosophically oriented radical social science (McLaughlin, 1999, p. 109) but it was (Nkoane 2013, p. 99) who posited that the CER proponents at the Frankfurt School could be likened to the emancipatory pedagogy of Marx. The task before CER scholars in the opinion of Demirovic (2009) is manifest in their desire to explain and encourage participation wherein the world will be a better place for all. To accomplish this, scholars of CER orientation problematised perspectives of social conditions such as issues of oppression, crisis and inequality substituting them with liberating options (Sinnerbrink, 2012:370). The rural folks are marginalized in every sense of the word and tertiary teachers suffer the same faith which explains why they are still on strike stretching over five (5) months. Therefore, CER is a relevant theory to address the challenges of learning in the time of COVID-19, because one of the objectives of the theory is to enable marginalized people, such as teachers, learners and education as a whole.

\section{E-Learning Deficit amidst Covid-19 Crisis in Nigeria}

Discussions towards e-learning teaching in Nigeria are quite novel but not new (Salami, 2020). What is probably new is the unanimity of opinion that e-learning is the way forward in a period 
of crisis. Digital learning is globally recognized and accepted for there is a wide increase in tertiary education enrolment across the globe. This quest for digital learning is, therefore, an alternative route to learning; making the same 'more acceptable to a wider population'. To add pep to the imperative of digital learning, the minister for Education, Professor Adamu Adamu in March 2020 held an online meeting vice chancellors or presidents of tertiary institutions. In the meeting, they deliberated the need to deploy digital learning procedures and techniques in the country (Salami, 2020:17).

Digital learning in Nigeria is long overdue but there are several challenges that government and education stakeholders are unwilling or unable to address. There are worries concerning unsteady electricity supply, inconsistent Wifi, lack of/insufficient ICT facilities, technicians and tutors in both the urban and rural areas. All these constitute impediments to optimal ICT services in the teaching and learning of courses in Nigerian universities despite the research-oriented nature of these citadels of learning (the Federal Republic of Nigeria, 1998:5). Virtual learning is not new, what is needed is to incorporate it into the conventional system of education in the country. This has not been done for it has been a gimmick of sort by politicians and public officeholders. To rub the pains very deeply into the wounds of complacency, a scholar teased that:

But for now that the behemoth of a disease has suddenly and completely separated us from our campuses, classes and long term companion called black, white boards, and the smart board in a few cases, the reality of the need to embrace real digitized learning has dawned on everyone (Punch, 18 May 2020).

The minister's meeting with heads of institutions yielded a resolution by way of ministerial instruction issued in a fiat-like manner that institutions should 'immediately commence' the implementation of e-learning. But that is the problem of governance in Nigeria whereby authoritarian decree or policy is decreed into action. The minister pretended not to know the illpreparedness of the universities he superintends. There is a total absence of internet infrastructure and resources in majority of the public universities except in a few private universities. The elearning deficit across the universities is a pointer to the crisis in the sector. It would seem that there is a seeming justification of the ASUU position on improving education standards across the country which includes internet resources for alternative learning initiatives. In several Nigerian universities, staff members pay to the management (Ikedi, 2000) for internet facilities even when such authorities end up not providing the service or at the very best provide same in an epileptic manner (Ikegwu, 2020). Few institutions have started what appear to be e-learning procedures in their jurisdictions but this is a far cry to the optimum required to make headway in education under this pandemic season. Do we have obstacles or reasons for this avoidable deficit? Can this gap be filled and how fast?

And could these institutions be equipped with the necessary infrastructure to play the role expected of them by deploying e-learning resources in an effective and enduring manner?

No public university has responded to the minister's instruction in technological diversification in tertiary teaching for now. The idea is to continue or restart academic learning outside the conventional classrooms. States such as Oyo, Lagos, Osun and Edo that own tertiary institutions have launched various initiatives to tap into this 'new normal' initiative. While the Oyo government set up a subcommittee to ensure a stress-free alternative learning options in their eight higher 
institutions, Edo state government launched a package it christened EdoBest even as the Lagos state government moved swiftly to put in practice alternative options to learning in its tertiary institutions (Punch, 18 May 2020). These initiatives are a little too late but the challenges must have to be overcome.

\section{The Covid-19 and e-learning in Nigeria: The Way Forward}

Strong political will is needed to reverse the ugly trend in Nigeria's education system. To weed out the rot, there must be a deliberate and concerted effort by the government to do the needful. The Federal Ministry of Education shut down all secondary schools in Nigeria on March 23, 2020, to curtail the spread of the pandemic (FME,2020:9) and rolled out The Learn from Home Programme (LHP). In rolling out this initiative, experts expressed a measure of reservation because it focused only on an insignificant percentage of students, leaving millions of tertiary students to their indeterminate fate since the month of March 2020. Integrating ICT into the education system in Nigeria requires huge funding by a politically willing government but inadequate funding has been identified as one of the main hindrances to growth in Nigeria's public education sector (Ebenezar et al, 2020:12).

On the face value, it would appear that the education budget has relatively increased over the years, however, despite the key recommendation of UNESCO that developing economies should allocate $15 \%$ to $20 \%$ of their annual budget to education (Ebenezar et al, 2020:11), Nigeria has regularly observed this in breach allocating a meagre $8 \%$ maximum in the past ten years (FME, 2020, Nigerian Bureau of Statistics).

From the Focus Group Discussions (FGD), we arrived at the major challenges associated to the integration of ICT to education using students from three Southeastern universities in Nigeria, namely the University of Nigeria, Nsukka, Nnamdi Azikiwe University, Awka and Enugu State University of Science and Technology Enugu; all of which are public universities. There might be a measure of variation between public and private universities in responding to the pandemic owing to paucity of funds but majority of the private universities have found a way round the pandemic using e-learning options. The FGD has shown that the major concern of students in e-learning hovers around the often-recited challenges of access to data and power supply (Okonkwo, et al, 2020-Focus Group Discussion). Several students further identified the style of teaching by their teachers as a challenge and hindrance to their understanding of the core issues of e-learning.

Significant number of e-learning teachers and instructors were not fully compliant with the rigors and techniques of virtual and digital learning resources. So there is the observed deficit in the required digital literacy to effectively deliver content through the utilization of e-learning platforms (Okonkwo, et al, 2020- Focus Group Discussion). Lecturers and

instructors that spoke similarly situated their challenges around access to data and epileptic power supply. An insignificant number of the students were very conversant with e-learning with a far greater number not comfortable with the digital method of learning. Very curiously, over half of the students showed displeasure with continuing their academic pursuit online while the rest showed enthusiasm to continue. In concluding the FGD, we discovered that students' response throughout the interaction was anchored on the key challenges stacked up against them which must be addressed to make it easy for them to adapt and learn online. 
There is no doubt that COVID-19 disrupted many sectors across the globe but it is also true that long before the pandemic arrived several countries had in place strategic response options especially in the area of education. Emphasis on e-learning did not commence in the aftermath of the pandemic; it has long been integrated into the learning process in many countries. So while African states scamper to integrate e-learning into their learning schedule, developed countries plough their energy into advancing the sector beyond e-learning. The Nigerian example is most pathetic for, with decades of rot and decadence in the education sector leading to industrial disharmony with university teachers, the present haphazard response is merely expected. When professed intentions are at perpetual variance with expressed actions, many will note with pain that government position is always regularly garnished with hypocrisy. Or how do we classify a government with this bold strategic thought and yet flounders pitiably at implementation? The government said it will engage in 'robust, dynamic and effective response to mitigate the effect and impact of COVID - 19 on the education sector' and 'this requires a concise strategy to create an enabling framework for quality planning and effective implementation' (Fed. Min. of Educ.2020).

Interestingly and beyond rhetoric, the government has allowed tertiary education in the country to be halted because; there is no enabling framework, quality planning or even 'systemic and coordinated manner to safely carry out ancillary management' as professed by them. The pledge to do the needful has remained what it is - an intention. Worse still, all pronouncements by government expressing willingness (Ezigbo, 2020, FML\&E, 2020) in the area of engaging tertiary teachers with a view of ending their strike and returning them to the classroom has come with forlorn hope.

Going forward, addressing the issues of e-learning in Nigeria in the aftermath of COVID-19 pandemic requires at least seven broad areas of relevance for our attention and analysis. Summarily, the first is industrial harmony with different and divergent sectors of the economy. The next is education with a manifest interconnectedness to new things such as artificial intelligence, digitalization and technology. There is the dimension of the availability of food including security that constitutes the third, even as job security and employment make up the fourth. To diversify the economy and enhance exports coupled with good leadership present as the fifth while changes in lifestyle and travelling manifest as the sixth. The role of the civil society cannot be ignored in this process with the private and public sector working in synergy to safely annihilate the pandemic and take the country to the next level. From the foregoing, we have identified the issue of funding both in matters concerning tertiary teachers' strike and integration of ICT into the education system in Nigeria. It is our considered opinion that funding is key to all the anomalies spotted in this study. It is within this context that the study sees the imperative of increasing the annual budget for the sector to be in line with the recommendations of UNESCO. By whatever route or path, the minister of Education must figure out ways to collaborate with the National Assembly to increase Education budget in the next national annual budget. This may be done through the lobbying of the Assembly members especially members of the Senate and House Committees on Education. While the minister is chewing on the above, a $15 \%$ annual budget will be a good starting point for the 2021 budget even as he may desire to explore other options of raising funds through partnerships with the private sector. 
Furthermore, there is the urgent need to establish what we have called Village Learning Hubs (VLH) and Village Academic Clusters (VAC) to drive the vision of e-learning across the land. While the VLH will be domiciled inside the community libraries constructed for this purpose, VAC will be the team of instructors at the village level to drive the vision. The libraries will be equipped with e-learning devices, solar power and internet facility. In doing this, two interrelated achievements would have been recorded. First, the proposed VLH will revolutionize digital learning at the very grassroots while the VAC will revitalize community libraries that are fast disappearing in several communities across the country. The 'rurality' of this initiative is not in doubt but it essentially will address issues of unemployment and technical empowerment among the vulnerable youthful population.

While the industrial disharmony between tertiary teachers and government date back decades ago, the current dispute cannot be addressed without a deliberate return to the past. While much of the decay in the sector has been identified to be linked to the dearth of resources, there is an urgent need for prioritization of education to encapsulate the need to drive development and progress. Underfunding of existing public universities on the one hand and the proliferation of universities on the other encourages a conclusion of the deliberate stifling of the growth of public universities. What is more pragmatic is proper and adequate funding of the existing universities and less of issuing of licenses permitting private investments in the building more universities?

\section{Conclusion}

The study has shown problems in tertiary institutions in Nigeria especially given the recurring industrial disputes between the government and teachers. This has been worsened by the pandemic that placed itself on the consciousness of the world. The dual causative factor of COVID19 and tertiary teachers' strike reveals the global disparity in resources available to Africa's researchers. Their accomplishments are nothing short of impressive but there is a widening digital divide between developed world and developing societies so much so that key digital learning constraints like access to devices, lack of constant power supply, and high cost of reliable internet need to be addressed. Tertiary institutions may remain comatose if a lobby team fails to convince the national and state parliaments to increase budgetary allocation to education at the federal and state levels. There is no gainsaying the importance of enacting policies and legislations that 'mainstream education technologies in public institutions'. Scholars agree that with youth unemployment and underemployment rate soaring, keeping young people at home (which COVID-19 and teachers' strike has brought) without a definite engagement plan can only spell disaster for Nigeria.

\section{References}

Adavbiele, J. A. (2015), Implications of Incessant Strike Actions on the Implementation of Technical Education Programme in Nigeria. Journal of Education and Practice Vol.6, No.8, 2015 134, www.iiste.org ISSN 2222- 1735 (Paper) ISSN 2222-288X (Online), Access Date: 20/8/2020 
11| Tertiary Teachers Strike (TTS) and e-Learning Deficit amidst Covid-19 Crisis in Nigeria

Ajisegiri, W.S., Odusanya, O.O. And Joshi, R., (2020). 'Covid-19 Outbreak Situation in Nigeria and the Need for Effective Engagement of Community Health Workers for Epidemic Response'. Global Biosecurity, 1(4), p.None. DOI: http://doi.org/10.31646/gbio.69.

ASUU's Insensitive Strike, Editorial. (2020). Lagos: Vanguard Newspaper, April $8^{\text {th }}$.

Callaway E. (2020), Time to use the p-word? Coronavirus Enter Dangerous New Phase. Nature. 2020; 579.

Danilo Buonsenso, Bianca Cinicola, Francesca Raffaelli, Pietro Sollena and Francesco Iodice (2020). Social consequences of COVID-19 in a low resource setting in Sierra Leone, West Africa, International Journal of Infectious Diseases, Vol. 97, pp.23-26.

Demirovic, A. (2009, July). Foucault, Gramsci and Critical Theory: Remarks on their relationship Presentation at Workshop 2: Foucault and critical realism: Marx, Gramsci and Foucault, at the Cultural Political Economy Research Cluster of the Institute for Advanced Studies of Lancaster University. Retrieved from www.lancaster.ac.uk/cperc/docs/CR-Demirovic-Foucault.pdf

Dike, G. (2020) Covid-19: We Need Palliatives Too, Private School Teachers Owed 3 Months Salaries Cry Out" Daily Sun Newspaper Tuesday, July 7.

Du Plessis, P. \& Mestry, R. (2019). Teachers for Rural Schools - a Challenge for South Africa. South African Journal of Education, 39(1), 1-9.

Dube, B. (2020). Rural Online Learning in the Context of COVID-19 in South Africa: Evoking an Inclusive Education Approach, REMIE - Multidisciplinary Journal of Educational Research Vol. 10 No. 2

Ebenezar Wikina, Chimdi Chukwukere, Comfort Onyaga, Kehinde Adebiyi and Oteheri Akinruntan (2020). 'Nigeria's Public Education in a Post-COVID World: Strategies for Inclusive Learning in Tertiary Institutions', Policy Memo (Stanford/MIT Covid-19 Policy Hackathon, June 16.

Ebrahim, S. H., Ahmed, Q. A., Gozzer, E., Schlagenhauf, P., \& Memish, Z. A., (2020). Covid-19 and Community Mitigation Strategies in a Pandemic. BMJ, 2020(368), 1066. Retrieved from https://doi .org/10.1136/bmj.m1066

Ekiti State University Ado-Ekiti (2020) The Nation Newspaper, Tuesday, August 18.Ezeh, F, Ojo, J., and Ezeh, M. et al (2020) "Covid-19: FG Extends Phase 2 of Eased Lockdown by 4 Weeks, Reopens Schools for SS3, JSS 3, Primary 6 Pupils" Daily Sun, Newspaper Tuesday, June 30.

Ezigbo, O. (2020). FG in Fresh Moves to End ASUU Strike, Lagos: This Day Newspaper, August 5th

Federal Ministry of Labour and Employment (2020). FG assures an end to ASUU Crisis, Press Release. FML\&E, August 12 SS

Federal Republic of Nigeria (1998). National Policy on Education, Abuja: Federal Ministry of Education

Felter, C. (2020). What Is the World Doing to Create a COVID-19 Vaccine? Retrieved on the 20th of August 2020 from https://www.cfr.org/backgrounder/what-world-doing-create-covid-19-vaccine FME, (2020), Nigerian Bureau of Statistics).

Ggbolagunfe, B.(2020) "Students in Graduating Classes Resume in Oyo" Daily Sun Newspaper, Tuesday, July 7.

Glass, R. J., Glass, L. M., Beyeler, W. E., \& Min, H. J. (2006). Targeted Social Distancing Design for Pandemic Influenza. Emerging Infectious Diseases, 12(11), 1671 1681. https://doi.org/10.3201/eid1211 .060255

Hodges, C., Moore, S., Lockee, B., Trust, T., \& Bond, A. (2020). The Difference between Emergency Remote Teaching and Online Learning. Educause Review. 
Innocent Odoh (2020), ASUU declares indefinite strike over a disagreement with FG, Lagos: Business Day, March 23

Institute of Medicine. (2006). Modelling Community Containment for Pandemic Influenza. National Academies Press. https://doi.org/10.17226/11800

Krishnakumar, B. \& Rana. S. (2020). COVID 19 in INDIA: Strategies to Combat from Combination Threat of Life and Livelihood, Journal of Microbiology, Immunology and Infection, https://doi.org/10.1 016/j.jmii.2020.03.024

Lee, B. Y., Brown, S. T., Cooley, P., Potter, M. A., Wheaton, W. D., Voorhees, R. E., Stebbins, S., Grefenstette, J. J., Zimmer, S. M., Zimmerman, R. K., Assi, T.-M., Bailey, R. R., Wagener, D. K., \& Burke, D. S. (2010). Simulating School Closure Strategies to Mitigate an Influenza Epidemic. Journal of Public Health Management and Practice, 16(3), 252-261. https://doi.org/10.1097/PHH.0b013e3181ce594e.

Maila D. H. Rahiem (2020). The Emergency Remote Learning Experience of University Students in Indonesia amidst the COVID19 Crisis, International Journal of Learning, Teaching and Educational Research, Vol. 19, (6), pp.1-26, June (https://doi.org/10.26803/ijlter.19.6.1)

McCarthy, M. (2020, June). Dr Anthony Fauci: COVID-19 Will End and We Will Get Control Over It. Healthline. Retrieved from https://www.healthline.com/health_ news/dr-Anthony-Fauci-this-will-end-and-we-willget-control-over-it\#6

McKernan, J. A. (2013). The Origins of Critical Theory in Education: Fabian socialism as Social Reconstructionism in Nineteenth-Century Britain. British Journal of Educational Studies, 61(4), 417-433.

McLaughlin, N. (1999). Origins, Myths in the Social Sciences: From, the Frankfurt School and the Emergence of Critical Theory. Canadian Journal of Sociology, 24(1), 109-139.

Milman, N. B. (2020). Pandemic pedagogy. Phi Delta Kappan.

Moscona, A. (2005). Oseltamivir Resistance-Disabling Our Influenza Defences. New England Journal of Medicine, 353(25), 2633-2636. https://doi.org/10.1056/NEJMp058291

NCDC (2020). First Case of Corona Virus Disease Confirmed in Nigeria, Friday, February 28

Nkoane, M. M. (2010). Critical Liberatory, Inclusive Pedagogy: Arguing for a Zero Defect. Acta Academica, 43(4), 111-126.

Nkoane, M. M. (2013). Creating Sustainable Postgraduate Supervision Learning Environments Through Critical Emancipatory Research. TD: The Journal of Transdisciplinary Research in Southern Africa, 9(3), 393-400.

Ogbette, Afamefuna Samuel, Eke, Israel Emenike Ori \& Ogbonnaya Eze (2018). Causes, Effects And Management of ASUU Strikes in Nigeria, 2003-2013, Journal of Research and Development, Vol. 3 (3), pp.14-15

Ohiaa, C., Adeleye, S. Bakareyb, Ahmad, T (2020), COVID-19 and Nigeria: putting the Realities in Context, International Journal of Infectious Diseases (95), 279-281

Okonkwo, J. et al, 2020, Leader of the Focal Group Discussion in Nsukka, Enugu and Awka.

Osabuohien, E.S.C and Ogunrinola, I.O (2015), Causes and Effects of Industrial Crisis in Nigeria: Some Empirical Clarifications [Online]. Covenant University Repository: Nigeria. Access Date: 29/8/2020. Retrieved from: http://eprints.covenantuniversity.edu.ng/id/eprint/4400

Otobo, P. (1988), State and Industrial Relations in Nigeria. Lagos: Malthus press 
13 $\mid$ Tertiary Teachers Strike (TTS) and e-Learning Deficit amidst Covid-19 Crisis in Nigeria

Oyesola, B. (2020) 'Covid-19 Disrupts Education of More Than 70 Percent of Youth" Daily Sun Newspaper, Monday, August 17

Reynolds, K. A. (2020). Coronavirus: Fauci says Vaccine Possible by end of 2020. Medical Economics. https://www.medicaleconomics.com/news/coronavirus-fauci-says-vaccine-possible-end

2020 Resumption of Schools and Interstate Travels Editorial (2020) Daily Sun Newspaper, Tuesday, July,9

Sadique, M. Z., Adams, E. J., \& Edmunds, W. J. (2008). Estimating the Costs of School Closure for Mitigating an Influenza Pandemic. BMC Public Health, 8(1), 135. https://doi.org/10.1186/1471-2458-8-135

Salami Ayobami (2020). 'COVID-19 and the e-learning in our Tertiary Institutions Need', Lagos: Punch Newspapers, May 18

Schmidt, J. (2007). The Eclipse of Reason and the End of the Frankfurt School in American Schools. American Educational Research Journal, 33, 757-798.

Shibeshi, A. (2006). Education for Rural People in Africa. FAO/IIEP. Sinnerbrink, R. (2012). Critical Theory as Disclosing Critique: A Response to Kompridis. Constellations, 19(3), 370-381.

Sinnerbrink, R. (2012). Critical theory as disclosing critique: A response to Kompridis. Constellations, 19(3), 370-381.

The Universities (Miscellaneous Provisions) (AMENDMENT) ACT 1993)

Wale Odunsi, (2020). 'ASUU lists 6 reasons for Agitations, recurring strike', Lagos: Daily Post, March 12

World Health Organization. (2020). The draft landscape of COVID-19 candidate vaccines - 15 May 2020.World Health Organisation. Retrieved on 20th August 2020 from https://www.who.int/whodocuments detail/draft-landscape-of-COVID-19- candidate-vaccines.

World Health Organization. Coronavirus Disease (COVID-2019) R\&D [Internet]. WHO. World Health Organization; [cited 2020. April 24]. Available: from: http://www.who.int/blueprint/prioritydiseases/key-action/novel-coronavirus/en/.

Professor Victor Ukaogo holds a PhD in History and Strategic Studies from the University of Lagos where he had all his training. He is with the Department of History and International Studies, University of Nigeria, Nsukka, Nigeria. He is well published with a recent book 'Dilemma of the Bat: Africa and Globalization in a Changing World'.

Florence O. Orabueze had all her education at the University of Nigeria, Nsukka, and currently a professor in the Department of English and Literary Studies of the same University. She is widely published and has two collections of poems. As an astute university administrator, she has served as director of the Centre for African Studies and the university Bookshop amongst other positions.

Ojukwu, Chika Kate, PhD is a lecturer 1 in the department of English and Literary Studies, University of Nigeria, Nsukka. She had all her education from the University of Nigeria where she obtained her PhD in Pragmatics in 2016. Her research interests include: applied Linguistics, Pragmatics and Discourse Studies. She is a growing academic scholar with zeal. 


\section{Appendix:}

\section{Focus Group Discussion (FGD) Questions}

1. What are the major challenges of learning during this lockdown and how can such situation be addressed?

2. In what way(s) did the teacher's strike affect you as an individual?

3. What is your understanding, appreciation and use of any of the e-learning resources available to you?

4. How easily available are these resources?

5. Which of the learning options are you more comfortable with; traditional learning methods or e-learning alternative?

6. In what way(s) and to what extent would you blame the government in the ongoing crisis in the education sector?

7. How would you assess your e-learning instructors?

8. As an instructor, what major setback are you currently experiencing in the discharge of your duties? 